\title{
Healing notes: singing for well-being in an African bank
}

\author{
$A \operatorname{VAN} A S^{l}$
}

\begin{abstract}
In 2005, Dr Steve Booysen - then Group Chief Executive of the Absa Group - initiated an internal choir festival as a platform for social interaction and teambuilding of staff across all cultures, age groups and post levels in the bank. Towards the end of 2005, based on the widely held perception that the effects of the project had exceeded all expectations, it was decided to repeat the initiative, which has since become an annual event. To date, Absa has invested, and continues to invest, millions of rands in their choir project - confirmation that choir participation offers valuable benefits to the ordinary employee. This paper uses data from an investigation into the 'extra-musical benefits of this project to reflect on the value of the 2005-2008 Absa choir project for building social capital and strengthening individuals' sense of coherence (SOC) through singing together.
\end{abstract}

Key words. Choir, social capital, sense of coherence, cultural diversity

\section{Introduction}

This paper is a personal narrative of my experience and observations of the annual Absa internal choir competition during the years 2005-2008. It should be noted that the terms 'Absa choir competition', 'Absa internal choir competition' and 'Absa choir project' are used interchangeably in the paper. My involvement in this project and specifically as mentor for all Absa choirs in the country, afforded me countless hours to work with and observe the choirs. The experience provided numerous glimpses of the impact that choral singing had on the inter- and intra-personal relationships of the singers. The narrative draws from qualitative data obtained through open-ended questionnaires, notes and reflections in my journal and diaries, photographs and video material.

\section{Prologue}

Early in January 2005 I received a telephone call that I will probably never forget. The caller invited me to compose a choral song for an Absa choir competition. I had never heard of such a competition. All sorts of warning lights went off in my head: If the biggest banking group in the country was sponsoring a choir competition, it was likely to be buge; many outstanding choirs in the country (some world-class, really) were likely to participate; composing a competition song to be studied by these choirs - and especially their conductors - would be a 
daring endeavor; if I were to go ahead and put forth my own composition in such a domain, I would be subjecting my work to unnerving public critique.

So I asked my first question: "Which choirs are participating?"

The answer totally baffled me. This was an internal Absa competition. Ordinary bank employees from different branches, regions and business units would form choirs and compete to identify firstly provincial winners and finally the national winning choir. I later found out that Dr. Steve Booysen, then newly appointed Group Chief Executive of the Absa Group, had initiated the Absa Internal Choir Festival/Competition. This happened at the time of Barclays' investment of hundreds of billions of rands that would translate into its assuming a controlling share in Absa. A key role player in the negotiations, Booysen was aware that the merger would introduce a period of significant changes - possible restructuring could mean job losses, reshuffling of staff could require employees to move to new positions, business units or branches, under new management with new expectations responding to new company values in a new company culture. Booysen recognized these uncertainties as a potential threat to the morale of the Absa workforce and envisaged the choir project as a tool for team and spirit building for Absa employees during this phase of transformation in the Bank. And he had the courage to follow his instinctive conviction that singing together in choirs could help navigate his staff through the merger.

I said yes, I would love to write the Absa song for this unique competition.

I had no idea what an Absa song was. Much later I would learn from the work of Graham Welch that the use of specially composed company songs to reinforce company culture exemplifies singing as a form of group identification and social bonding (Welch 2005). I contacted key role players in the project and asked them what Absa would like their people to sing. These conversations brought an understanding that Booysen, who had a deep respect for former president Mandela and his esteem of ubuntu, felt passionately about nationbuilding. He wanted his staff to develop a sense of togetherness and to construct wholesome views of and relationships with colleagues of different cultural and ethnic backgrounds and, very importantly, he wanted them to have fun in the process. The song would have to include more than one official South African language.

I was invited to participate in a panel discussion to establish principles for the Absa Internal Choir Festival. This provided me with an opportunity to promote my notion of more through music, than for music. As Booysen wanted every Absa employee to be free to join an Absa choir, there would be no auditions allowed in forming these choirs - literally, 'whosoever will, may come'.

Absa is a major national organization in South Africa and so their staff represents a wide range of groups working in almost every conceivable region in the country. Absa choirs were formed in different regions of every South African province, comprising male and female members between 18 and 65 years of age, representing different cultural, religious, ethnic and language groups employed at different post levels in the Bank.

The message of the Absa song evolved around the catchy Absa slogan Today, Tomorrow, Together and in general endeavored to simply convey the message of 'together we can'. Not knowing what the choirs would be able to master, I set out to compose a song made up of simple melodies and natural harmonies, with some contrast and ample repetition, for soprano, alto, tenor and/or bass. 
The day before the final competition in July 2005, as choirs appointed as provincial winners arrived at the venue, the excitement was palpable. Observing all the activity - choirs rehearsing on stage in preparation for the final, socializing and interacting with other choirs, having last minute practices in hotel rooms or outside in the cold, singing their own choral slogans in corridors to keep their spirits up - I realized that something 'deeper' was happening here. The singing together of Absa employees in choirs appeared to have produced by-products not envisaged when the choir competition was initiated. The following snapshots show members of the first Absa massed choir whole heartedly singing the refrain of the 2005 Absa song. Choir members' enjoyment of the singing as well as conviction of the message of the song is evident in the images. The three different choirs in the images can be identified by their individual choir uniforms.

Words: And we shall stand together, we shall walk together, we shall run together we shall win the race

And we shall celebrate each other as a sister and brother and honour child and mother - we are a special race

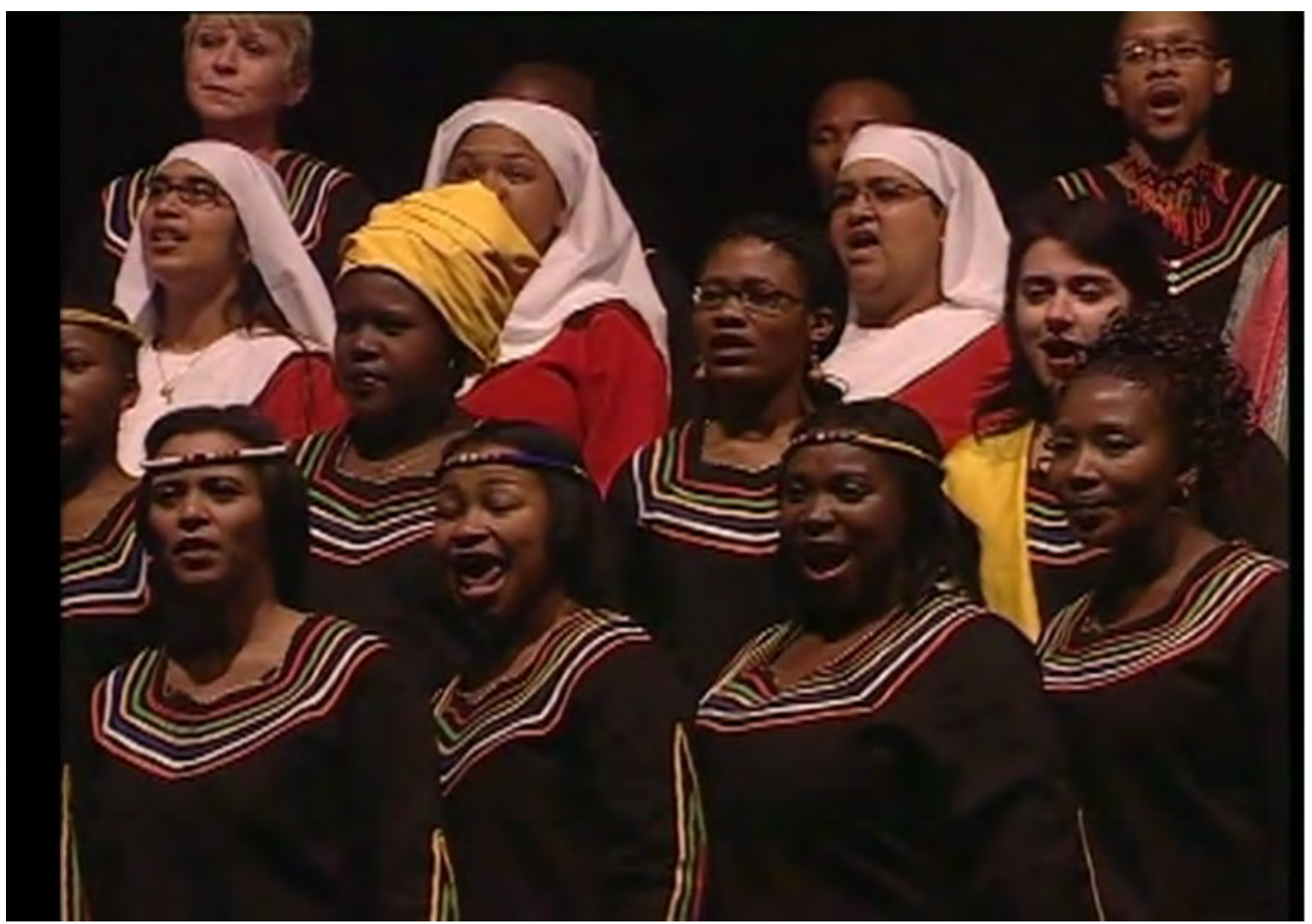

Figure 1a: Eastern Cape (black uniforms) and Western Cape (Red uniforms) participating in the 2005 


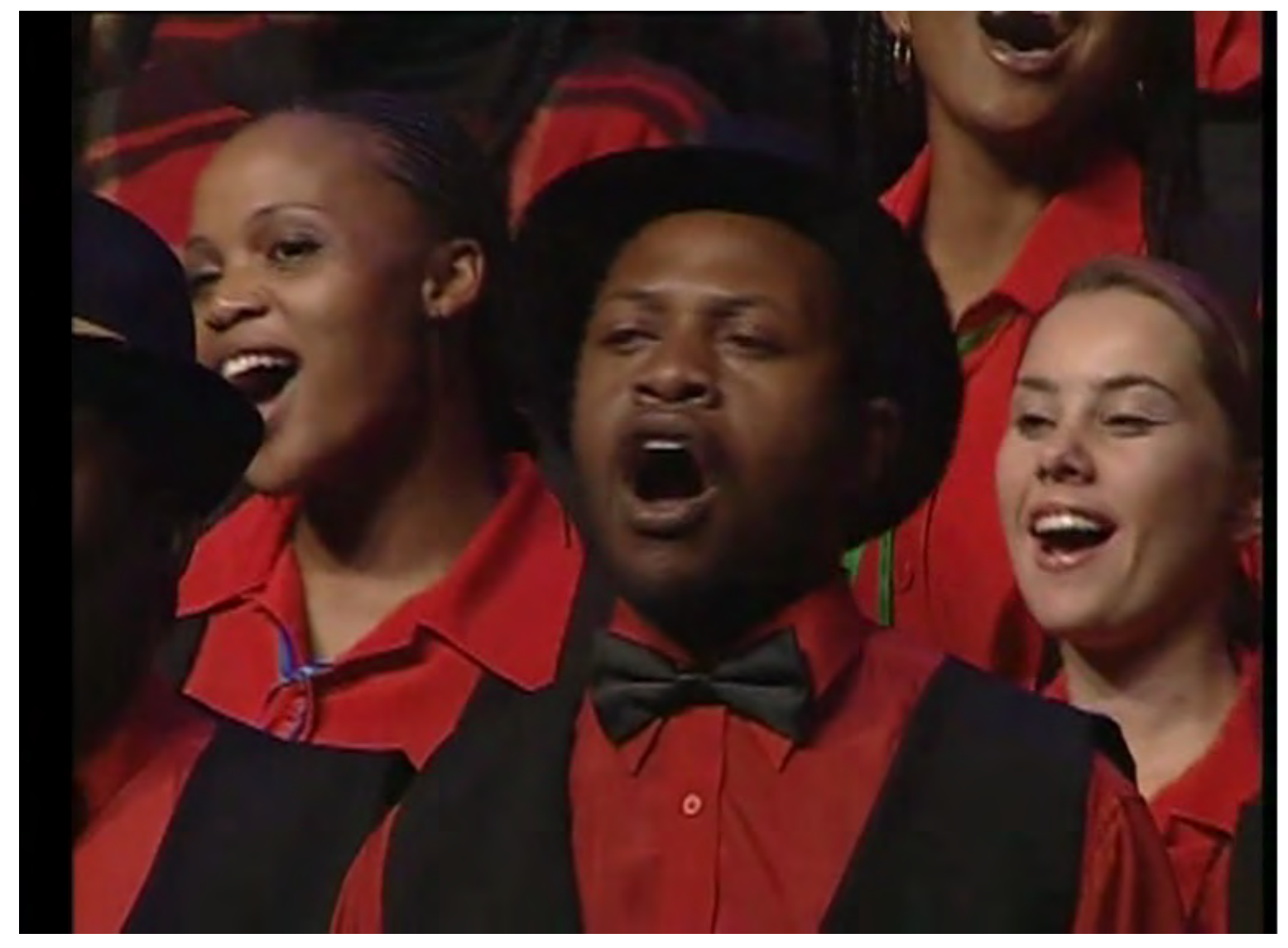

Figure 1b: Gauteng choir members singing in the massed choir item

And so the Absa Internal Choir Competition (AICC) took root as an annual institution and my doctoral investigation of choir participation as a tool for transformation and teambuilding in a corporate environment began, with Absa Bank as a case study. I was commissioned to compose three more Absa songs for the 2006 to 2008 choir competitions and in 2007 I was contracted as external service provider to mentor all Absa choirs across the country, teaching the Absa song and mentoring each choir's own choice item. 


\section{Theoretical framework}

The paper is framed by the concepts of 'social capital' and 'salutogenic sense of coherence $(\mathrm{SOC})^{2}$.

\section{Social capital}

One of the fundamental ideas associated with social capital is that social networks have value. Social capital involves people becoming connected through being sociable. Lyda Judson Hanifan, a state supervisor of rural schools in West Virginia in the early twentieth century, was the first to use the principles of social capital by advocating community involvement in the development of successful schools. He refers to social capital as 'those tangible substances that count for most in the daily lives of people: namely good will, fellowship, sympathy, and social intercourse among the individuals and families who make up a social unit' (Hanifan 1916: 130). Few concepts in the field of sociology have gained as much recognition or as many disciples over such a short period of time as is the case with social capital. It is therefore understandable that the discipline has been criticised for lack of clarity in the conceptualisation of the term (Schaefer-Mc Daniel 2004: 154). Definitions include "social networks and the norms of reciprocity and trustworthiness that arise from them" (Putnam 2000: 19); 'the ability of people to work together for common purposes in groups and organizations' (Portes 1998: 6); 'the sum of the resources, actual or virtual, that accrue to an individual or a group by virtue of possessing a durable network of more or less institutionalised relationships of mutual acquaintance and recognition (Bourdieu and Wacquant 1992: 119); 'the information, trust, and norms of reciprocity inhering in one's social networks' (Woolcock 1998: 153); and 'Social capital is defined by its function. It is not a single entity, but a variety of different entities having two characteristics in common: They all consist of some aspect of social structure, and they facilitate certain actions of individuals who are within the structure' (Coleman 1994).

Woolcock (2001) describes three types of social capital namely bonding, bridging and linking. Bonding social capital refers to the relationships built among people who have much in common such as members of families and ethnic groups. Bridging social capital refers to relationships built with people who have little in common, such as people who are from a different socio-economic status, different ethnicity or a different generation. These relationships are "likely to be more fragile, but more likely also to foster social inclusion." (Schuller et al.: 2000: 5).

Linking social capital refers to "social relations with those in authority, which might be used to garner resources or power" (Stone and Hughes 2002: 3). Social capital differs from other types of capital in that it increases in value when used (OECD 2001). There is now a range of evidence indicating that societies and individuals dealing generously in social capital are likely to benefit from lower crime figures, better health, higher educational achievement and better economic growth (Halpern 2009).

Harvard political scientist Robert Putnam is widely acknowledged for popularizing the concept of social capital. Putnam's work focuses mainly on bonding and bridging social

\footnotetext{
2 In 1979 Antonovsky introduced salutogenesis as an alternative approach in medicine. The sense of coherence is the core construct of the salutogenic model.
} 
capital. He explains that connected people grow to be less suspicious, more tolerant, and also more compassionate towards the adversity of others. People whose lives are rich in social capital have improved abilities to fight illnesses and cope with stress and traumas.

Judd et al. (2001: 368) identify a link between notions of social capital and salutogenesis in that both these concepts focus on activities that could maximize the health and quality-of-life of individuals, families and communities.

\section{Salutogenesis and the sense of coherence}

Antonovsky (1979) introduced salutogenesis as an alternative approach in medicine. The term is derived from the Latin salus (health) and the Greek genesis (birth), indicating a focus on that which gives birth to health. Since the introduction of salutogenesis, the work of Antonovsky has become very influential and his salutogenic approach and sense of coherence theory has been researched and applied in fields such as medicine, nursing, psychopathology and health psychology (Griffith 2009).

In the salutogenic approach the health/disease relation is perceived as a continuum. Salutogenesis is concerned with a person's movement toward the health pole of the health/disease continuum (Antonovsky 1991). It focuses on strengthening peoples' resources and capability to overcome setbacks and create personal health. Traditionally medical science focuses on risk factors (pre-disposing factors causing disease) and pathogens (organisms causing disease) and aetiology (how risk factors and pathogens cause disease). Salutogenesis focuses on strengthening general resistant resources to support movement toward the health pole of the ease/dis-ease continuum.

The core construct in the salutogenic model is the sense of coherence (SOC). The SOC is the ability to make sense of life and make use of coping strategies (Henry 2013: 19). It consists of three components:

- Comprehensibility - the belief that the world is orderable and that demands (challenges) can be understood;

- Manageability - the belief that the resources needed to cope with the demands are available. These resources can be one's own or that of a trustworthy other (e.g. God or a friend). In the workplace, factors such as social support and appreciation from workmates and superiors act as primary resources (Kalimo et al. 2002: 232);

- Meaningfulness - the wish to cope and the ability to perceive the demands as challenges worthy of emotional investment (Strang and Strang 2001: 127). Antonovsky (1991) regarded meaningfulness as 'the crucial motivational component'.

A stronger SOC brings about a higher level of overall well-being. Through strengthening an individual's meaningfulness, comprehensibility and manageability it would be expected that 'feelings of despair, hopelessness and entrapment would be reduced, and a brighter and more recovery-focused, life-affirming and compelling future could be created and internalized' (Griffith 2009). 


\section{Choir, Absa choirs, social capital and SOC: presentation and discussion of data from the research project}

Janice Chapman, Australian born singer and teacher, and recipient of the Order of Australia medal, notes that the true power of music is illustrated when ideas and passions in music are communicated through the medium of another human or group of humans. She continues: 'It is a very big idea: that singing enhances and balances lives and can be so powerful a force that people without it feel bereft and diminished' (Chapman 2006: 264). Communicating ideas through choral singing involves much more than everybody merely learning to sing all the lines of the choral songs correctly. Pavel Chesnokov, one of the most prolific Russian composers of sacred choir music of the early 1900s, noted that to transform the mere sound of human voices into a focused choral tone, the singers need to achieve levels of excellence in three areas:

- Ensemble: Balance and blending of all voices and voice groups to obtain a homogenous sound;

- Intonation: Precision in the tuning of the melodies and harmonies to achieve beauty of sound; and

- Nuances: Fulfilling the conductor's demands to achieve vocal expressivity (Chesnokov 2010: 5).

For a choir to obtain excellence in these three categories, each choir member needs to continuously assess his/her own singing, adapt his/her intonation, blend the tone of his/her voice with all the voices around, and respond expressively to the leading of the conductor. This requires continuous focus and listening. Erie (1999) observes: 'If the eyes are the mirror of the human soul, then the voice is the barometer of human emotion'. In working with many choirs over many years I have come to understand that communicating human emotion through choral singing is richly rewarding but necessitates uninterrupted sensitive listening, openness to the music and conductor, and a sincere desire to communicate meaning to the audience.

Every year the Absa choir competition ${ }^{3}$ expects choirs to achieve all of the above in two categories: 1) the prescribed Absa song and 2) the 'own choice' item (see below). However, before an Absa choir begins the journey of becoming an expressive vocal instrument, it has to overcome a number of significant hurdles. Firstly, employees who are eager to participate have to take initiative and start campaigning amongst ordinary bank employees from different cultural, language and age groups until they have enrolled enough members to constitute a choir. Suitable candidates must be prepared to sacrifice considerable personal time, balance professional, social and family responsibilities and commit to weekly or biweekly practices for a period of six months. Once formed, each choir must appoint a choir conductor from among their members - someone whose directing and leadership all members are willing to follow whose 'will is their will' when singing (Chesnokov 2010: 6). Then they must organise regular practice times suitable to all and find an appropriate venue for the practicing. As most practices take place after a normal day's work, members must organise beverages. In the event of a full-day practice, meals must also be provided. In more rural areas where choir members live in different towns and have to travel long distances to attend, practices usually take place over weekends (often on Sundays) to allow for adequate travelling time to and from the practice venue. For members of the Christian faith this translates to missing the traditional

The choir project is still an annual event in Absa. In 2012 it was renamed as Barclays Harmony. 
Sunday morning church services. This has been particularly hard for those in leadership positions in their church community, e.g. deacons, Sunday school teachers and members of 'worship teams'. Each year every choir must master the annual Absa song and select or arrange a song (or songs) for their own choice item. They are also expected to take full responsibility for their choir costumes - which are assessed as part of the adjudication at the final competition. Cultural diversity is a defining element of the Absa choirs. Sindane (1995) explains culture as largely prescriptive in nature. He explains: "It says, "This is how such and such is done'. Hence it is common to hear people say, 'in our culture, this is how we do it".

Another significant hurdle is presented in the conflicting views embedded in the different cultures, religions and age groups represented in the choirs. In my work this were foregrounded when songs for the 'own choice' item and decisions regarding the design of the choir uniform needed to be finalised. During these times I sensed that some members felt uncomfortable with the songs, movements and/or ideas for the choir uniform proposed by members of other cultures or age groups. While members from minority cultural groups seemed to feel that their opinions were of less value, members from majority groups seemed frustrated when it appeared that their preferences were overlooked even though they were the majority in the choir. However, it was interesting that, even when heated debates and feelings of irritation surfaced, I never witnessed decisions made simply by voting - not before members had invested a great deal of time (sometimes hours) and proposed a variety of compromises to negotiate a resolution acceptable to all.

I observed firsthand how culturally diverse groups of Absa employees developed, through conflict and misunderstanding, into cohesive teams characterised by goodwill, always wholeheartedly singing together 'as one'. More important than the cultural/other differences in the choir was a common goal shared by all: they wanted to be the best Absa choir in the country. Every member of the choir was an important role player in achieving this goal. And so every member belonged - became one of 'us' - everybody existing as a member of the choir community. Portes (1998: 6) identifies this ability of people to work together for common purposes in groups as a defining element of social capital.

At the same time that cultural diversity presented a challenging (and creative) process of bridging social capital, it also enriched the music. Choirs would intentionally include folk songs of all the cultural groups represented in the choirs. In cases where there were only one or two Afrikaans members, Afrikaans folk songs would be included in the repertoire. I believe that the purpose was to reflect the demography of the choir through the singing. But this practice also communicated a celebration of the diversity, acknowledging the different cultures represented as part of the collective identity of the choir through the singing. These non-professional singers became very skillful in weaving together multi-cultural medleys within the prescribed boundaries of the competition's three minutes limit in an aesthetically pleasing manner. Welch (2005: 254) notes that when fusion of music traditions of the diverse cultures within a choir occurs and established performance practices are modified, the singing becomes a transformative activity culturally.

Performing each other's traditional songs generated cultural empathy among Absa choir members. Cultural empathy is not sympathy with, or agreement with a specific culture. Rather, it is the appropriate understanding of a culture's values and beliefs (Zhu 2011: 117); "seeing the world through another's eyes, hearing as they might hear and feeling and experiencing their internal world" (Ivey et al. cited in Zhu 2011: 117). 


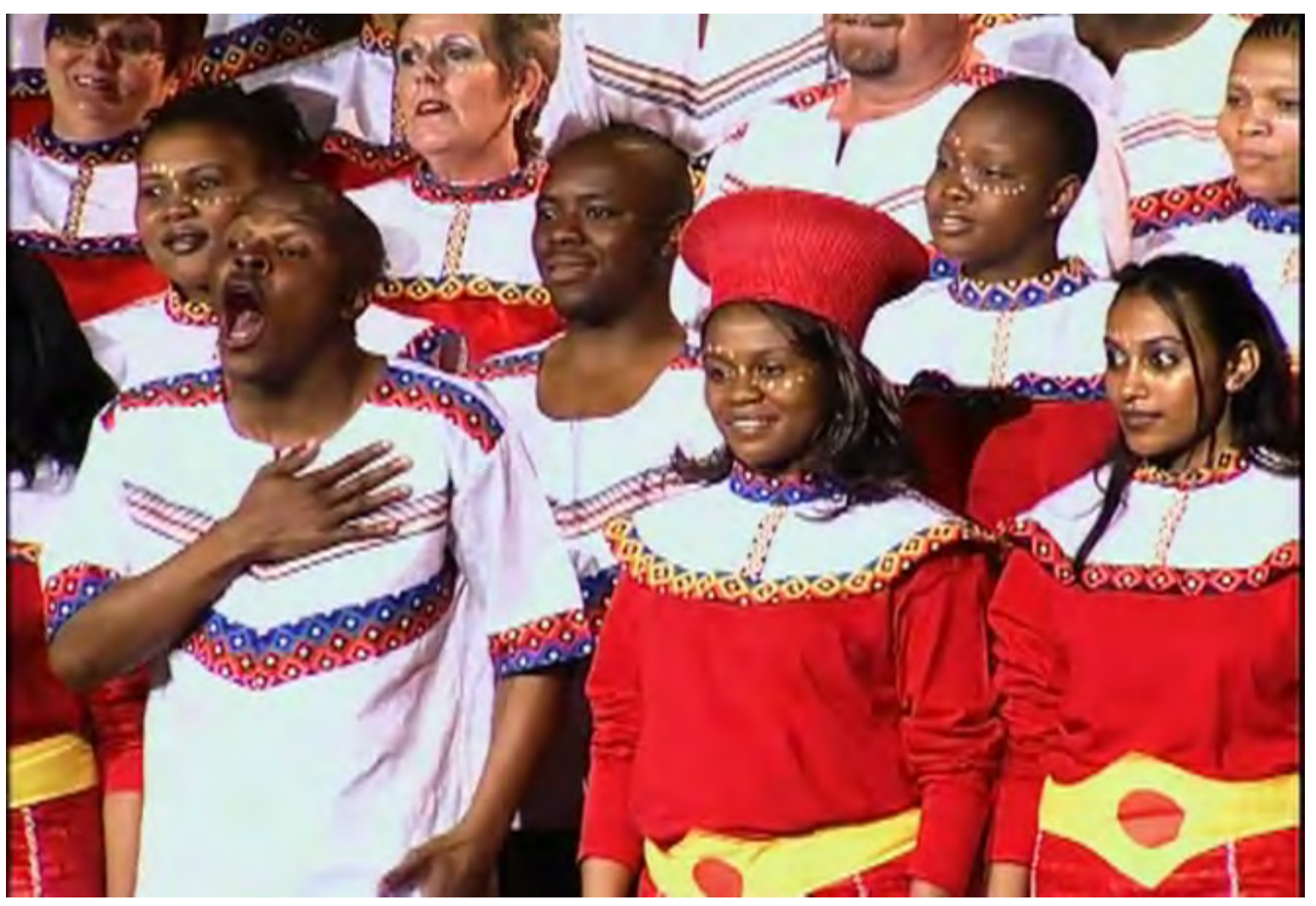

Figure 2a: Black soloist passionately singing My Sarie Marais

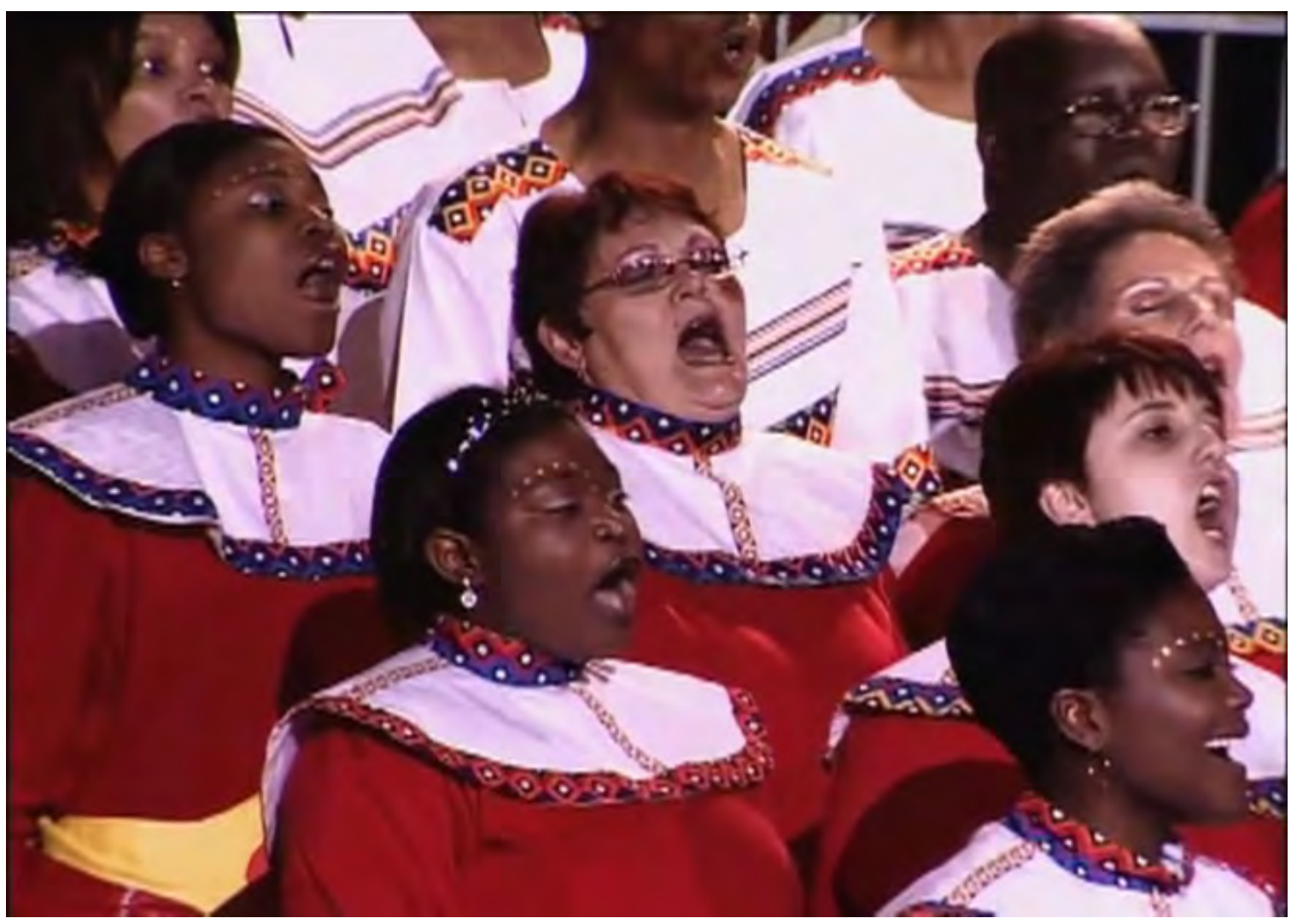

Figure 2b: White (Afrikaans) members eagerly singing eGalile 
The above figures of the Mpumalanga choir performing their own choice item illustrate choir members "seeing the world through another's eyes, hearing as they might hear and feeling and experiencing their internal world" through performing each other's cultural songs.

It was heartwarming to watch choir members grow in sensitivity to fellow choir members' differing cultural artefacts (in this case songs). An informal interview with three middle-aged Afrikaans females revealed that learning to sing and dance to the Sesotho song studied at the time, had bought about a sincere appreciation for the beauty of the language. One interviewee expressed sadness at not having discovered this earlier in her life. She said that she was 'now determined to learn to speak the language' as this would allow her to communicate with Basotho colleagues in their mother tongue. I found that Afrikaans popular music artists who can speak and/or include phrases from black languages in their Afrikaans songs seem to have endeared themselves to black choir members. Choirs were often eager to include such works in their repertoire.

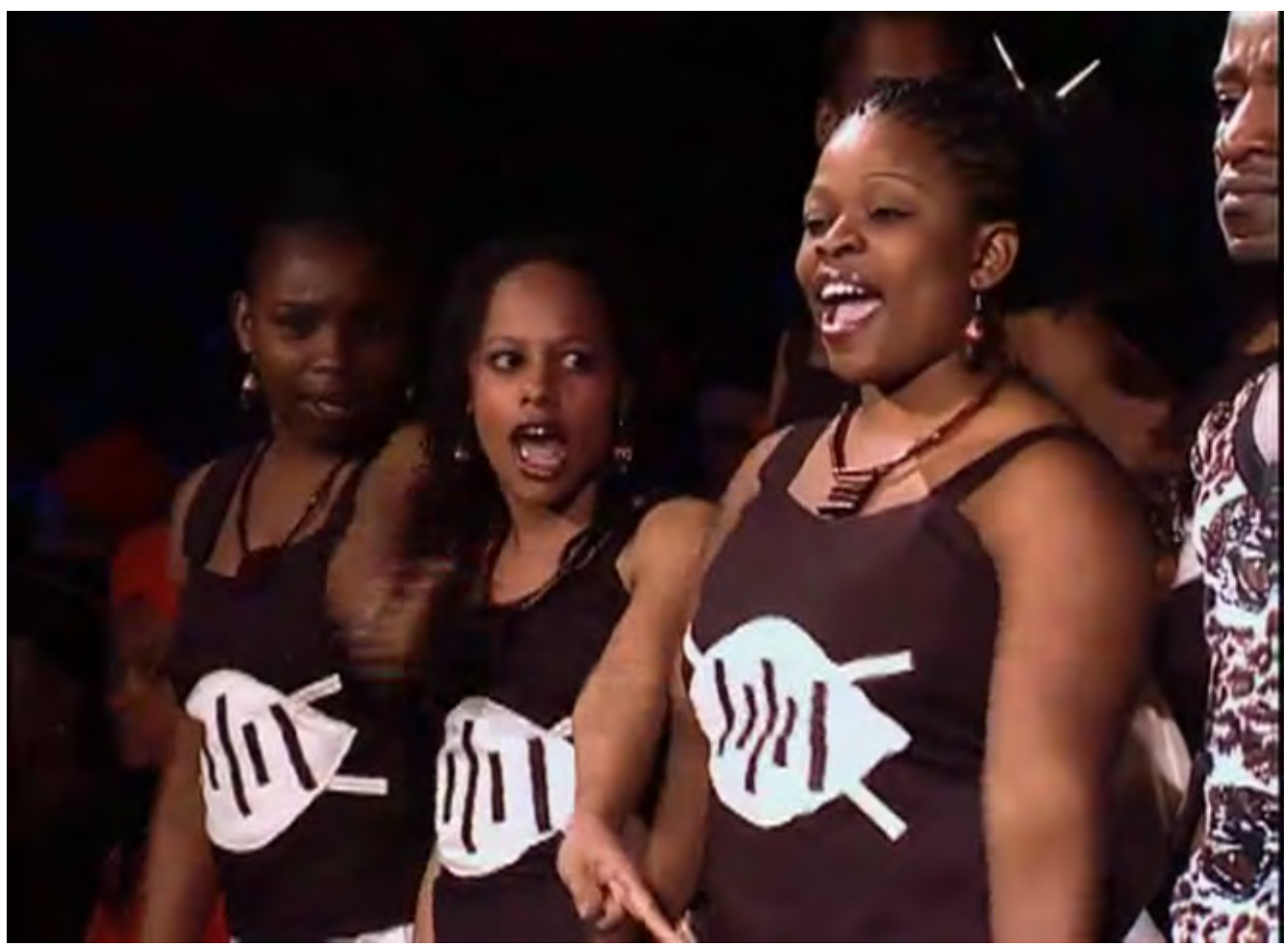

Figure 3a: Lyrics: "Vat jou goed en trek, Ferreira 


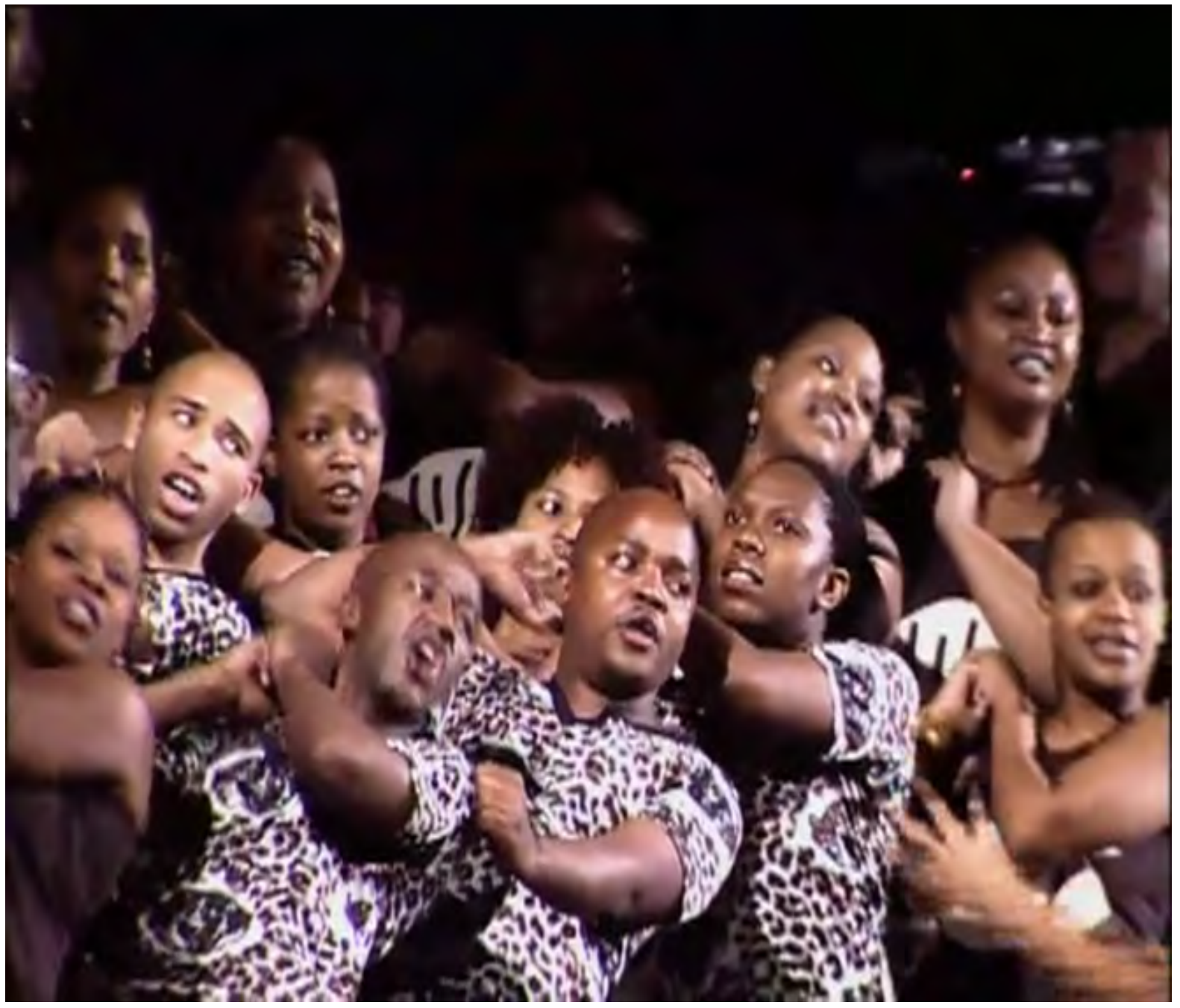

Figure 3b: Swaar dra al aan die een kant ..."

Members of the $2008 \mathrm{KZN}$ choir singing Vat jou goed en trek, Ferreira in their own choice item. Only one of the choir members was Afrikaans speaking (a white male). The fusion of music traditions is evident in the inclusion of movement (an important element of African choral music) in the performance of this Afrikaans folk song

Singing together, and specifically singing each other's cultural songs, created a bridging social capital in these choirs. In the qualitative data acquired through responses to open-ended questions in the questionnaire, 46 of the 461 respondents ${ }^{4}$ indicated that the single most important benefit the choir brought to their lives was that they gained new understanding of and bonds with people of differing cultures. Comments included:

"I think differently about cultures that I didn't know much of before"

"I feel that others are more positive about my culture"

"We are from different cultures but we are together"

\footnotetext{
${ }^{4}$ The questionnaire was administered at three interventions over three years. Not all participants chose to answer all the open-ended questions.
} 
"I love the new friendships with people who speak other languages"

"I am going to learn to speak an African language"

"We manage to teach white people how to dance to our music"

"I have learnt African dancing!"

It was always intriguing to watch black choir members teach white colleagues the correct pronunciation of words of traditional songs, explain the meaning and context of the lyrics and teach the dance movements with great patience. Interestingly, the data obtained indicated that the teaching and learning of the dancing which accompanied the African songs was an important milestone for both teachers and learners. Special care and attention was always given to colleagues with a physical impediment. On several occasions, Lydia, a blind Afrikaans speaking member in one of the choirs, said to me: "I live for this choir". She always expressed how she loved the African dancing, marveling at the warmth, care and humour evident when her colleagues coached her to master the movements with great precision. Indeed: 'Singing together (like bowling together) does not require shared ideology or shared social or ethnic provenance' (Putnam 2000: 411). Kalimo et al. (2002: 232) predict that such increase in available resources of 'trustworthy others' will contribute to an increased SOC in the lives of choral singers.

Singing in the choir had a positive influence on the singers' moods. 120 respondents viewed this as the single most important benefit of the choral singing. Comments included:

"Feeling good!"

"I am a happier person"

"I feel like a winner - even if we do not win the competition"

"The choir brings me joy"

"Relaxation - I stress less"

"It brought me peace"

"Singing in the massed choir was one of the most moving experiences of my life"

The choral singing seemed to have developed individuals' general resistant resources and to have led to a stronger SOC (Antonovsky 1991). 7 respondents reported that they had developed crucial leadership skills; 47 reported that they (or others) discovered their talent:

"I did not realize how musical I am!"

"My family and friends are amazed at my talent"

"I have gained a lot of recognition for my musical talent"

"People look at me differently after I sang the solo"

"I love music more than ever before"

True teambuilding encapsulates different notions of social capital and SOC. Teambuilding activities and recognition from management and colleagues develops a stronger SOC - and so increased well-being in individuals (Muller and Rothman 2009: 9). Collier (1998) regards Putnam's example of networks of trust and reciprocity developed through amateur choirs as the most famous example of social capital. Many respondents (134 choir members) indicated 
that the sense of belonging to a cohesive team was the most valued personal benefit of participating in the choir project. Comments included:

"I have learnt to be a better team player"

"The people in my choir respect me"

"I now know my colleagues with whom I spend a great deal of time"

"Togetherness - a sense of belonging"

"I have learnt to cooperate with others"

"I belong to a group where I feel appreciated'

Putnam (1993) describes how positive social capital is increased in amateur choirs: The choir members learn to trust each other even though this is not the purpose of their interaction. This causes a reduction in opportunistic behaviour when individuals balance own interests with that of the networks they have learnt to trust which results in reduced transaction costs. Choir participants learn to trust not just other members of the choir but other members of society. Hence, the choirs benefit even non-participants. A case in point: In 2007 the reciprocity between the (culturally diverse) members of the Western Cape choir benefited the South African wheelchair bowling team. A choir member was selected as a member of the national team to compete in an international handicapped bowling championships. However, the team had not received sufficient sponsorship to cover all their costs. Her fellow choir members stepped in with enthusiasm and organised a number of fundraising events and were able to raise the money needed.

In 2007 I experienced vividly the significance of a sense of belonging to a team for a Northern Cape choir member. This provincial choir comprised members from Absa branches in various towns in the province. The distances between the towns posed a real challenge for choir practices, as many choir members would have to travel for many hours to attend the practices. I arrived early one Sunday morning at the McGregor museum in Kimberley, an hour before the practice was to commence, and was surprised to find a young woman waiting on the steps of the museum. I was astonished to learn that she had hitch-hiked 700 kilometers through the night as she did not have any other form of transport to get her to the venue in time for the choir practice. When I asked her why she would go to such lengths, putting herself in possible danger, her response was simply: "We are a team. They depend on me".

In 2008 Booysen noted that the statistics of the Absa choir project indicated that 5003 employees had participated in the choral singing in that year. 2008 was also the year when a wave of xenophobia wreaked havoc in many townships in the country. A member of the Mthata choir (the only racially homogenous Absa choir at the time) told me that the following verse in the 2008 Absa song (which they were constantly rehearsing in preparation for the competition) served as a compass for their choir during these sad times:

Rata hona joale (Love this moment)

Ithate (Love and give back to yourself)

Rata bang basatsoaning le oena (Love those who are different from you)

Rata bopelo! (Love life!) 
This was a clear indication of the deep importance and meaning that singing had in the choir members' lives and how they used it to process deeply felt emotions and in this case maybe confusion and pain felt in the wake of the violence.

\section{Conclusion}

Absa's daring venture to capitalize on the power of choral singing, as an investment in their human capital is indeed a very big idea. It demonstrates the suitability of choir to 1) generate trust and reciprocity between South Africans of differing cultural and language backgrounds, so promoting a bridging social capital and 2) promote teambuilding and employees' sense of belonging to a group, strengthening participants' SOC and so improving individual and group well-being.

When the idea of the choir was first floated, it was largely to give employees the opportunity to have fun, socialize and get to know each other... It has certainly achieved those three objectives, and so much more. The truth is: at the time we had no idea what was taking root. This initiative transformed people's lives ... and brought business benefits no training programme could hope to imitate. (Booysen 2007)

I recently had the privilege of adjudicating at the 2013 final choir competition - now termed Barclays Harmony. The choir competition has now expanded and includes choirs from twelve African countries, allowing the expansion of social capital and sense of coherence through choral singing across the planet.

I am very grateful for that phone call in January 2005.

\section{References}

Antonovsky, A. 1991. The salutogenic approach to family system health: Promise and danger. European Congress on Mental Health in European Families, Prague. Retrieved on 12 July 2013 from http://goo.gl/VZgRLQ

Bourdieu, P. and Wacquant, L.J.D. 1992. An Invitation to Reflexive Sociology. Chicago: University of Chicago Press.

Booysen, S. 2007. Opening address. The Third Absa Internal Choir Competition. Sandton.

Chapman, J.L. 2006. Singing and Teaching Singing: A Holistic Approach to Classical Voice. Oxford: Plural Publishing.

Chesnokov 2010. The choir and how to direct it: a handbook for choral conductors. Musica Rusica, San Diego, California.

Coleman, J.S. 1994. Foundations of Social Theory. Cambridge: Harvard University Press.

Erie (1999) Voice of Emotion The Speech-Language Pathologist's Role in Managing Stress Related Voice Disorders. London Speech and Language Centre. Retrieved on 9 August 2013 from http://www.londonspeech.com/article7.htm

Griffiths, C.A. 2009. Sense of coherence and mental health rehabilitation. Clinical Rehabilitation 23: 72-78. Retrieved on 3 September 2013 from http://goo.g1/cJ0BIL 
Hanifan, L. J. 1916. The rural school community center. Annals of the American Academy of Political and Social Science 67: 130-138.

Halpern, D. 2009. Capital gains. RSA Journal Autumn 2009. Retrieved on 24 July 2013 from http://www.thersa.org/fellowship/journal/features/features/capital-gains

Henry, H. 2013. Asset-based thinking part 2: an asset-based approach to creating health. Nursing Times 109 (4) 19-21. Retrieved on 16 June 2013 fromhttp://goo.g1/UEDa1N

Judd, J., Frankish, C.J. and Moulton, G. 1991. 2001. Setting standards in the evaluation of community-based health promotion programmes - a unifying approach. Health Promotion International 16 (4): 367-380.

Kalimo, R.,Pahkin, A. and Mutanen, P. 2002. Work and personal resources as long-term predictors of well-being. Stress and Health 18: 227-234.

OECD. 2001. The Well-being of Nations: The Role of Human and Social Capital, Education and Skills. OECD Centre for Educational Research and Innovation, Paris, France.

Schaefer-McDaniel, N.J. 2004. Conceptualizing Social Capital among Young People: Toward a New Theory. Children, Youth and Environment, 14 (1): 140-150.

Schuller, T., Baron, S., \& Field, J. (2000). Social capital: a review and critic. In S. Baron, J. Field, \& T. Schuller (Eds.). Social Capital. Oxford: Oxford University Press.

Sindane, J. 1995. Democracy in African societies and Ubuntu. Pretoria: Human Sciences Research Council.

Stone, W. and Hughes, J. 2002. Social capital: Empirical meaning and measurement validity. Retrieved on 17 August 2013 from http://goo.gl/qsC2S1

Strang S, and Strang P. 2001. Spiritual thoughts, coping and sense of coherence in brain tumor patients and their spouses. Palliat Med 15:127-34.

Welch, G.F. 2005. Singing as communication. In D. Miell, R. MacDonald and D. Hargreaves (Eds). Musical communication.

Woolcock, M. 1998. Social Capital and Economic Development: Toward a Theoretical Synthesis and Policy Framework. Theory and Society 27(2): 151-208. Retrieved on 7 September 2013 from http://goo.gl/qoxUMB

Woolcock, M. 2001. The place of social capital in understanding social and economic outcomes. Isuma: Canadian Journal of Policy Research 2(1): 1-17. Retrieved on 3 August 2013 from http://goo.g1/g059rB

Zhu, H. 2011. From Intercultural Awareness to Intercultural Empathy. English Language Teaching 4(1):116-119. 